\title{
Characterization of Physico-Chemical and Spectroscopic Properties of Biofield Energy Treated 4-Bromoacetophenone
}

\author{
Mahendra Kumar Trivedi ${ }^{1}$, Alice Branton ${ }^{1}$, Dahryn Trivedi ${ }^{1}$, Gopal Nayak ${ }^{1}$, Gunin Saikia ${ }^{2}$, \\ Snehasis Jana ${ }^{2, *}$ \\ ${ }^{1}$ Trivedi Global Inc., Henderson, USA \\ ${ }^{2}$ Trivedi Science Research Laboratory Pvt. Ltd., Hall-A, Chinar Mega Mall, Chinar Fortune City, Hoshangabad Rd., Bhopal, Madhya \\ Pradesh, India
}

Email address

publication@trivedisrl.com (S. Jana)

\section{To cite this article:}

Mahendra Kumar Trivedi, Alice Branton, Dahryn Trivedi, Gopal Nayak, Gunin Saikia, Snehasis Jana. Characterization of Physico-Chemical and Spectroscopic Properties of Biofield Energy Treated 4-bromoacetophenone. American Journal of Physical Chemistry.

Vol. 4, No. 4, 2015, pp. 30-37. doi: 10.11648/j.ajpc.20150404.11

\begin{abstract}
Bromoacetophenone is an acetophenone derivative known for its usefulness in organic coupling reactions and various biological applications. The aim of the study was to evaluate the impact of biofield energy treatment on 4bromoacetophenone using various analytical methods. The material is divided into two groups for this study i.e. control and treated. The control group remained as untreated and the treated group was subjected to Mr. Trivedi's biofield energy treatment. Then, both the samples were characterized using X-ray diffraction (XRD), differential scanning calorimetry (DSC), thermogravimetric analysis (TGA), Fourier transform infrared (FT-IR), gas chromatography-mass spectrometry (GC-MS), and $\mathrm{UV}$-visible spectrometry (UV-vis). The XRD study revealed that the crystallite size of treated 4-bromoacetophenone was decreased significantly to $16.69 \%$ with decreased intensity as compared to the control. The thermal studies revealed that the slight change was observed in the melting point and latent heat of fusion $(\Delta \mathrm{H})$ of biofield energy treated sample as compared to the control. Maximum degradation temperature $\left(\mathrm{T}_{\max }\right)$ of treated 4-bromoacetophenone was decreased by $7.26 \%$ as compared to the control $\left(169.89^{\circ} \mathrm{C} \rightarrow 157.54^{\circ} \mathrm{C}\right)$. The FT-IR spectra showed that the $\mathrm{C}=\mathrm{O}$ stretching frequency at $1670 \mathrm{~cm}^{-1}$ was shifted to higher frequency region (1672 in T1 and $1685 \mathrm{~cm}^{-1}$ in T2, in two treated samples for FT-IR) after biofield energy treatment. Moreover, the GC-MS data revealed that the isotopic abundance ratio of either ${ }^{13} \mathrm{C} /{ }^{12} \mathrm{C}$ or ${ }^{2} \mathrm{H} /{ }^{1} \mathrm{H}(\mathrm{PM}+1) / \mathrm{PM}$ was decreased up to $9.12 \%$ in $\mathrm{T} 2$ sample whereas increased slightly up to $3.83 \%$ in $\mathrm{T} 3$ sample. However, the isotopic abundance ratio of either ${ }^{81} \mathrm{Br} /{ }^{79} \mathrm{Br}$ or ${ }^{18} \mathrm{O} /{ }^{16} \mathrm{O}(\mathrm{PM}+2) / \mathrm{PM}$ of treated 4-bromoacetophenone was decreased from $0.10 \%$ to $1.62 \%$ (where PM-primary mass of the molecule, $(\mathrm{PM}+1)$ and $(\mathrm{PM}+2)$ are isotopic mass of the molecule). The UV spectra showed the similar electronic behavior like absorption maximum in control and treated samples. Overall, the experimental results suggest that Mr. Trivedi's biofield energy treatment has significant effect on the physical, thermal, and spectral properties of 4-bromoacetophenone.
\end{abstract}

Keywords: 4-Bromoacetophenone, Biofield Energy Treatment, Fourier Transform Infrared,

Differential Scanning Calorimetry, Thermogravimetric Analysis, X-ray Diffraction,

Gas Chromatography-Mass Spectrometry

\section{Introduction}

4-Bromoacetophenone is basically a natural product and found in the environment as degradation products of industrial chemicals. It is used as a basic starting material in most of the metal catalyzed coupling reactions due to the presence of both electron-rich and electron-withdrawing functionalities within the same molecule [1]. In biological systems, halogen bonding has its importance due to their high directionality and specificity. Therefore, they can be used effectively in drug design to direct the binding of ligands to the target sites [2]. The bromoacetophenone derivatives upon excitation with ultraviolet radiation can generate phenyl 
radicals. The utility of haloarenes were studied by Paul et al., as radical progenitors for DNA cleavage. It is reported that haloarenes are readily available compounds upon UV excitation and halo acetophenones are effective DNA cleaving agents $[3,4]$. 4-Bromoacetophenone has been used as basic starting material in coupling reactions such as Heck coupling, Suzuki coupling, and Stille reactions [5]. Furthermore, guaiacyl, syringyl, and $p$-hydroxyphenyl-type bromoacetophenone derivatives were synthesized as the starting materials for $\beta-O-4$ type artificial lignin polymers [6]. Apart from that, the acetophenones were screened for activity against positive phototaxis of Chlamydomonas cells, a process that requires coordinated flagellar motility. Several acetophenones including 3, 4-dimethylacetophenone, and 4ethylacetophenone showed inhibitory effects on phototaxis in Chlamydomonas, in a concentration-dependent manner, indicating that these compounds nonspecifically interfere with phototaxis by disrupting overall cell viability [7].

Due to their wide range of applications in biology and synthetic organic chemistry, the objective of the current study was to evaluate the impact of biofield energy treatment on the physical and chemical properties of 4bromoacetophenone. The biofield is defined as the complex dynamic electromagnetic (EM) field. The field resulting from the EM fields contributed by each individual oscillator or electrically charged ensemble of particles of the body (ion, molecule, cell, tissue, etc.) $[8,9]$. The term "biofield" has been accepted by the U.S. National Library of Medicine as a medical subject heading [10]. The biofield, which surrounds the human body, can be harnessed from the Universe. It has been applied on materials or living things by experts in a controlled way to make the changes [11]. Mr. Trivedi's unique biofield energy treatment is known as The Trivedi Effect $^{(}$[12]. The Trivedi Effect has been applied in various research fields including microbiology research [13], agriculture research [14, 15], and biotechnology research [16]. Thus, by observing the various transformations happened due to the unique biofield treatment of Mr. Trivedi, this study aimed to evaluate the impact of biofield energy treatment on 4-bromoacetophenone with respect to their physical, thermal and spectral properties.

\section{Materials and Methods}

\subsection{Study Design}

4-Bromoacetophenone was procured from Loba Chemie Pvt. Ltd., India. The compound was divided into two parts i.e. control and treated. The control sample was remained as untreated and the treated sample in sealed pack was given to Mr. Trivedi for biofield energy treatment. Mr. Trivedi provided the treatment through his energy transmission process to the treated group. The control and treated samples were evaluated using various physical, thermal and spectroscopic techniques.

Percent change in various parameters in treated sample with respect to control was calculated using the following equation:

$$
\% \text { change }=\frac{[\text { Treated }- \text { Control }]}{\text { Control }} \times 100
$$

\subsection{X-ray Diffraction (XRD) Study}

The X-ray powder diffraction studies were carried out to characterize the crystallinity of 4-bromoacetophenone using Phillips, Holland PW 1710 X-ray diffractometer system, with radiation of wavelength $1.54056 \AA$ in the $2 \theta$ range $10^{\circ}$ $99.99^{\circ}$. The crystallite size $(\mathrm{G})$ was calculated by using the formula: $G=k \lambda /(b \operatorname{Cos} \theta)$. Here, $\lambda$ is the wavelength of radiation, $\theta$ is the corresponding Bragg angle, $b$ is full-width half maximum (FWHM) of the peaks and $\mathrm{k}$ is the equipment constant $(=0.94)$.

\subsection{Differential Scanning Calorimetry (DSC) Study}

The DSC thermogram of 4-bromoacetophenone was acquired using Perkin Elmer/Pyris-1, USA at the flow rate of $5 \mathrm{~mL} / \mathrm{min}$ using closed aluminum pan to determine the melting temperature and latent heat of fusion.

\subsection{Thermogravimetric Analysis (TGA)/Derivative Thermogravimetry (DTG)}

TGA/DTG results were obtained using Mettler Toledo simultaneous thermogravimetric analyzer at a heating rate of $5^{\circ} \mathrm{C} / \mathrm{min}$ from room temperature to $400^{\circ} \mathrm{C}$ under air atmosphere.

\subsection{FT-IR Spectroscopic Analysis (FT-IR)}

FT-IR characterization was done with Shimadzu Fourier transform infrared spectrometer (Japan) with the frequency range of $500-4000 \mathrm{~cm}^{-1}$. 4-bromoacetophenone was run as pressed disks using $\mathrm{KBr}$ as the diluent.

\subsection{GC-MS Spectrometry Analysis}

The gas chromatography-mass spectrometry (GC-MS) analysis was performed on Perkin Elmer/auto system XL with Turbo Mass, USA, having detection limit up to 1 picogram. The GC-MS spectrum was obtained as \% abundance $v s$. mass to charge ratio $(\mathrm{m} / \mathrm{z})$. The isotopic ratio of $(\mathrm{PM}+1) / \mathrm{PM}$ and $(\mathrm{PM}+2) / \mathrm{PM}$ was expressed by its deviation in treated samples as compared to the control.

\subsection{UV-Vis Spectroscopic Analysis}

UV-Vis spectra of control and treated samples were obtained from Shimadzu UV spectrophotometer (2400 PC) with quartz cell of $1 \mathrm{~cm}$ and a slit width of $2.0 \mathrm{~nm}$. The analysis was done at the wavelength range of 200-400 nm.

\section{Results and Discussion}

\subsection{XRD Studies}

The XRD study was conducted on both control and treated samples of 4-bromoacetophenone and diffractograms are 
shown in Figure 1. Both control and treated 4bromoacetophenone samples exhibited very sharp and intense peaks of intensity 1350 a.u. and 630 a.u., respectively in their X-ray diffractogram. The control 4bromoacetophenone exhibited the XRD peaks at $2 \theta$ equal to $19.05^{\circ}, 28.71^{\circ}, 38.57^{\circ}$, and $49.04^{\circ}$ (Table 1). However, the XRD diffractogram of treated 4-bromoacetophenone showed the XRD peaks at $2 \theta$ equal to $18.91^{\circ}, 20.45^{\circ}, 23.28^{\circ}, 28.57^{\circ}$, $38.46^{\circ}$, and $48.62^{\circ}$, with decreased intensity as compared to the control. The crystallite size was calculated using Scherrer formula and found decreased after biofield treatment by $16.69 \%$ in the treated 4-bromoacetophenone. It was reported that the strain produced by energy milling had reduced the crystallite size in the crystal [17]. Thus, it is assumed that biofield energy treatment might induce the energy that causes milling in the treated 4-bromoacetophenone which is responsible for a decrease in crystallite size.

Table 1. XRD analysis of control and treated 4-bromoacetophenone.

\begin{tabular}{|c|c|c|c|c|}
\hline & $2 \theta$ & FWHM of peak intensity $100 \%$ & $\begin{array}{l}\text { Crystallite size } \\
\text { 'G' } \mathrm{G} 10^{-9} \mathrm{~m}\end{array}$ & $\begin{array}{l}\text { Percent change in } \\
\text { 'G' wrt control }\end{array}$ \\
\hline Control & $19.05,28.71,38.57,49.04$ & 0.12 & 85.43 & \\
\hline Treated & $18.91,20.45,23.28,28.57,38.46,48.62$ & 0.14 & 71.17 & -16.69 \\
\hline
\end{tabular}

FWHM: full width half maximum, wrt: with respect to.

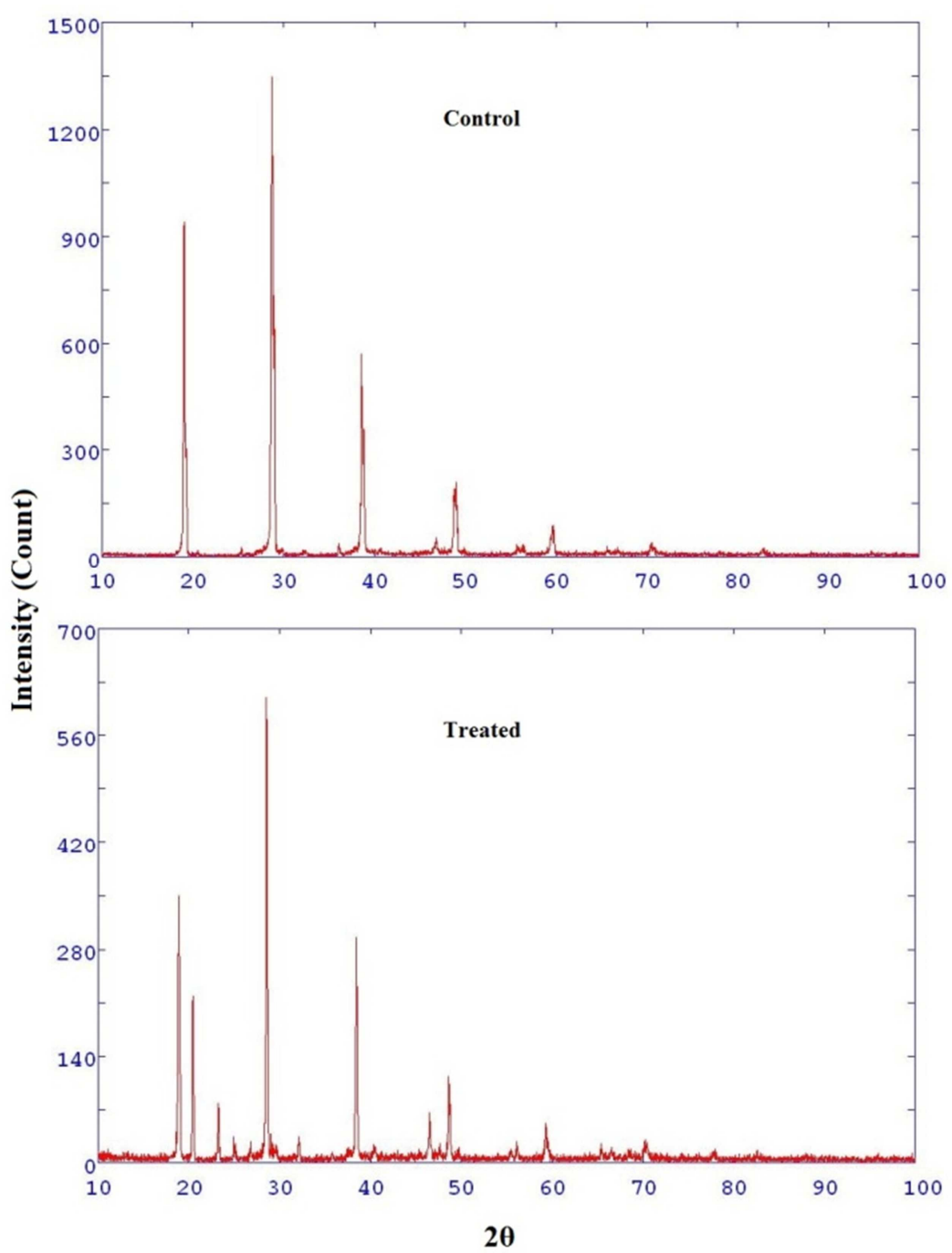

Fig. 1. X-ray diffractograms of control and treated samples of 4-bromoacetophenone.

\subsection{DSC Analysis}

Measurement of melting point and latent heat of fusion $(\Delta \mathrm{H})$ was done using DSC analysis. The melting point and $\Delta \mathrm{H}$ of control and treated samples of 4-bromoacetophenone are presented in Table 2. The latent heat of fusion $(\Delta \mathrm{H})$ was decreased in the treated 4-bromoacetophenone from 230.55 $\mathrm{J} / \mathrm{g}$ to $228.38 \mathrm{~J} / \mathrm{g}$. A lower melting point was observed in the treated 4-bromoacetophenone $\left(54.44^{\circ} \mathrm{C}\right)$ as compared to the control sample $\left(55.22^{\circ} \mathrm{C}\right)$, (Table 2$)$. This result showed that 
treated 4-bromoacetophenone sample needed less energy in the form of $\Delta \mathrm{H}$ to undergo the process of melting at a lower temperature after biofield energy treatment. It is hypothesized that the biofield energy might reduce the intermolecular force in the treated 4-bromoacetophenone molecules, which possibly decrease the melting point and latent heat of fusion.

Table 2. DSC analysis of control and treated 4-bromoacetophenone.

\begin{tabular}{llll}
\hline Parameter & Control & Treated & $\begin{array}{l}\text { Percent } \\
\text { change }\end{array}$ \\
\hline Latent heat of fusion $\Delta \mathrm{H}(\mathrm{J} / \mathrm{G})$ & 230.35 & 228.38 & -0.85 \\
Melting point $\left({ }^{\circ} \mathrm{C}\right)$ & 55.22 & 54.44 & -1.41 \\
\hline
\end{tabular}

\subsection{TGA/DTG Analysis}

The TGA/DTG thermograms of both control and treated samples of 4-bromoacetophenone are shown in Figure 2. TGA curve showed that the control and treated samples were degraded in one step. In control 4-bromoacetophenone, the onset temperature was at $128.69^{\circ} \mathrm{C}$ and endset at $199.86^{\circ} \mathrm{C}$. However, in treated sample, onset temperature was observed at $124.95^{\circ} \mathrm{C}$ and endset at $186.66^{\circ} \mathrm{C}$. In this process, the control sample lost $59.24 \%$ of its initial weight, whereas treated sample lost $57.44 \%$ of its initial weight. The DTG thermogram showed the $\mathrm{T}_{\max }$ at $169.89^{\circ} \mathrm{C}$ and $157.54^{\circ} \mathrm{C}$, respectively in the control and treated sample. Thus, the decrease in maximum degradation temperature of treated 4bromoacetophenone can be related to decreasing in thermal stability. The overall decreases in thermal stability of treated sample might be advantageous to be used as a reaction intermediate in coupling and photo excitation reactions.
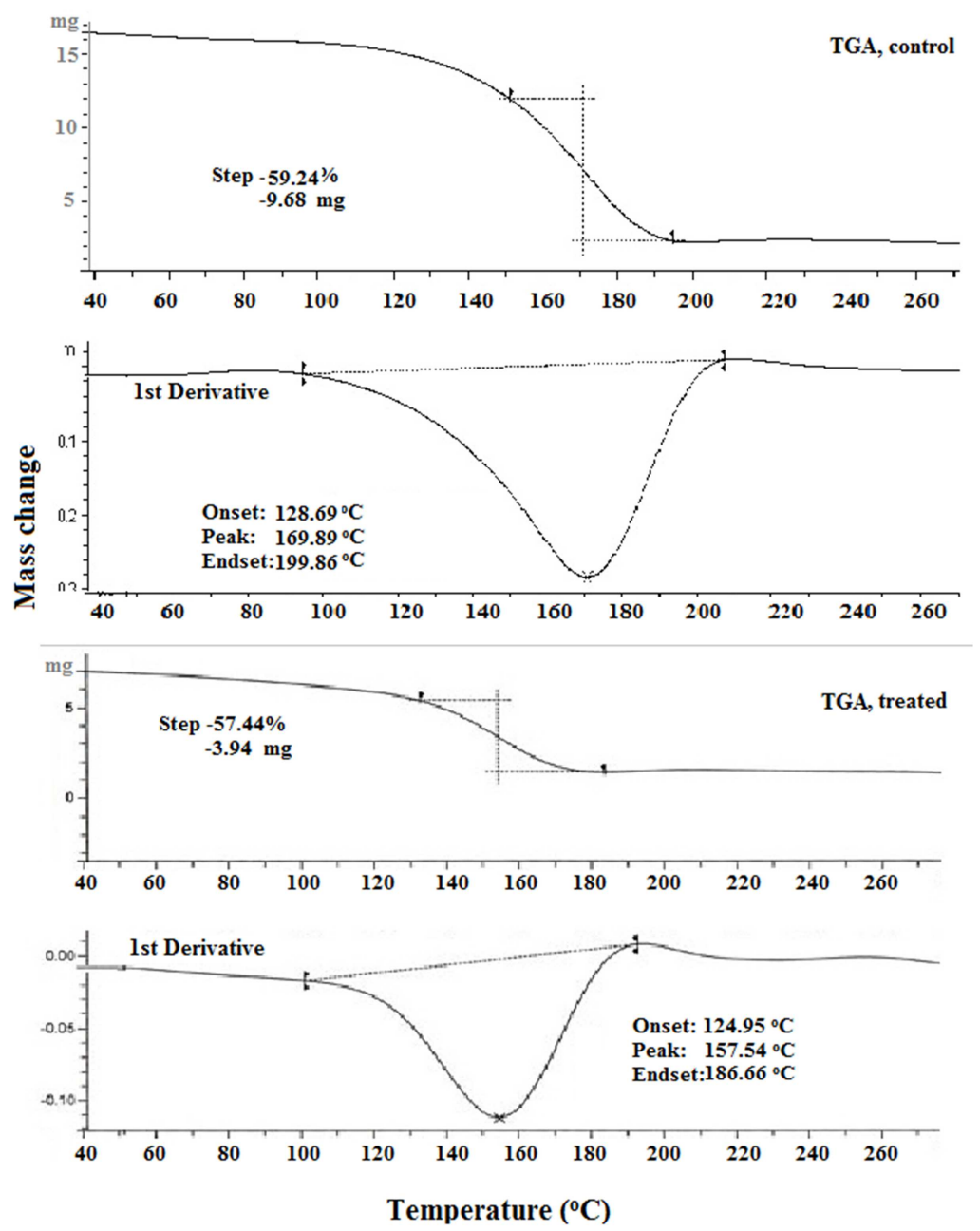

Fig. 2. TGA-DTG thermogram of control and treated samples of 4-bromoacetophenone.

\subsection{FT-IR Analysis}

The treated sample of 4-bromoacetophenone was divided into two parts as T1, and T2. The FT-IR spectra of control and treated samples of 4-bromoacetophenone are presented in Figure 3. The FT-IR spectra showed the aromatic C-H stretching frequency at $3010 \mathrm{~cm}^{-1}$ for control and treated samples of 4-bromoacetophenone. The IR spectra of control 4-bromoacetophenone sample showed $\mathrm{C}=\mathrm{O}$ stretching at $1670 \mathrm{~cm}^{-1}$, however in treated samples the $\mathrm{C}=\mathrm{O}$ stretching frequency shifted to higher energy region $\left(\mathrm{T} 1=1672 \mathrm{~cm}^{-1}\right.$, $\left.\mathrm{T} 2=1685 \mathrm{~cm}^{-1}\right)$. The carbon-halogen bond is stronger covalent bond and it can be easily identifiable and appeared at $609 \mathrm{~cm}^{-1}$, for the $\mathrm{C}-\mathrm{Br}$ bending vibration in both control and treated samples. The absorption at $1587 \mathrm{~cm}^{-1}$ and 1359 $\mathrm{cm}^{-1}$ in control sample are due to the $\mathrm{C}=\mathrm{C}$ stretching in 
aromatic ring $\left(1359 \mathrm{~cm}^{-1}\right)$ was first reduced to $1354 \mathrm{~cm}^{-1}$ and then increased to $1361 \mathrm{~cm}^{-1}$ in the treated $\mathrm{T} 1$ and $\mathrm{T} 2$ samples respectively. Furthermore, the $\mathrm{C}-\mathrm{H}$ deformation bends were assigned to the peaks at $1269 \mathrm{~cm}^{-1}$ in both control and treated samples of 4-bromoacetophenone. The FT-IR spectra indicated that there was a slight alteration in the $\mathrm{C}=\mathrm{O}$ and
$\mathrm{C}=\mathrm{C}$ stretching frequencies in the treated 4bromoacetophenone, which increased after biofield energy treatment. The FT-IR results did not show any major changes in vibrational frequencies for the aromatic $\mathrm{C}-\mathrm{H}$ stretching frequencies. The FT-IR spectral data is well matched with the literature data [18].

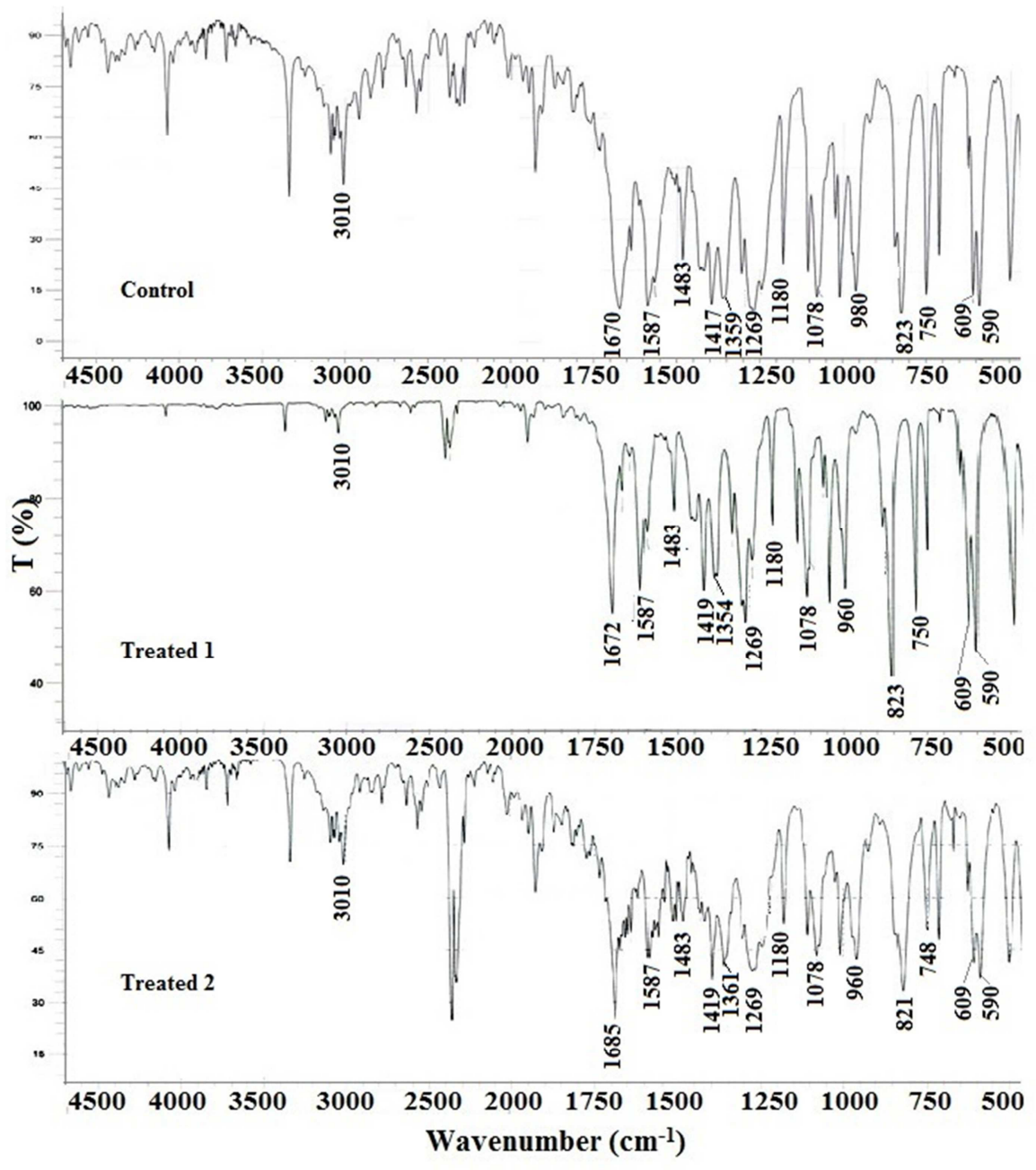

Fig. 3. FT-IR spectra of control and treated samples of 4-bromoacetophenone.

\subsection{GC-MS Analysis}

The treated sample of 4-bromoacetophenone was divided into four parts as T1, T2, T3, and T4. The mass spectra of control and treated samples of 4-bromoacetophenone are shown in Figure 4(a) and 4(b), respectively. The mass spectra showed the PM (primary molecule) peak at $m / z=198$ in the control and treated samples of 4-bromoacetophenone. The $\mathrm{m} / \mathrm{z}$ peak intensity, intensity ratio and isotopic abundance ratio of $(\mathrm{PM}+1) / \mathrm{PM}$ and $(\mathrm{PM}+2) / \mathrm{PM}$ peaks are presented in Table 3. There were six major peaks observed in both control and treated samples of 4-bromoacetophenone. The peaks are at $m / z=198,183,155,76,50$ and 43 due to 4bromoacetophenone and its degraded products. The degradation of 4-bromoacetophenone, corresponded to the following ions: $\mathrm{C}_{8} \mathrm{H}_{9} \mathrm{Br}^{+}$( $p$-bromoehtylbenzene), $\mathrm{C}_{6} \mathrm{H}_{5} \mathrm{Br}^{+}$ (bromobenzene), $\mathrm{C}_{6} \mathrm{H}_{5}^{+}$(benzene), $\mathrm{C}_{4} \mathrm{H}_{2}^{+}$(1, 3-butadyine) and $\mathrm{C}_{2} \mathrm{H}_{4} \mathrm{O}^{+}$(acetaldehyde), respectively were well matched with the reported GC-MS data [19]. The treated 4bromoacetophenone samples (T1-T4) were fragmented in a similar way with varied intensities as the control sample. Isotopic abundance ratio of $(\mathrm{PM}+1) / \mathrm{PM}$ and $(\mathrm{PM}+2) / \mathrm{PM}$ in 4-bromoacetophenone was calculated and presented in Figure 5. It is seen from the Figure 5 that the isotopic abundance ratio of $(\mathrm{PM}+1) / \mathrm{PM}$ in 4-bromoacetophenone was increased by $3.83 \%$ in $\mathrm{T} 3$ sample, while it was decreased by $9.12 \%$ in treated, T2 sample as compared to the control. However, the isotopic abundance ratio of $(\mathrm{PM}+2) / \mathrm{PM}$ in 4bromoacetophenone was decreased from 0.1 to $1.62 \%$ in $\mathrm{T} 1$ to T4 samples, as compared to the control. The biofield treatment may have altered the isotopic abundance ratio of $(\mathrm{PM}+1) / \mathrm{PM}$ and $(\mathrm{PM}+2) / \mathrm{PM}$ of treated 4bromoacetophenone from the control sample. Furthermore, it is assumed that the lower isotopic ratio of $(\mathrm{PM}+1) / \mathrm{PM}$ and 
$(\mathrm{PM}+2) / \mathrm{PM}$, might have decreased the stability of the compound due to the decreased $\mu$ (reduced mass) and binding energy in molecules with lighter isotopic bonds. This lower binding energy may lead to decrease the bond strength for treated 4-bromoacetophenone, however, the reverse might happen in treated T3 sample [20]. It is reported that the isotope fractionation for bromine and oxygen is slower than chlorine, carbon, hydrogen, and nitrogen, which is much dependent on the reaction path (kinetic) of organohalogen compounds [21], and we have observed a slow depletion of $(\mathrm{PM}+2) / \mathrm{PM}$ ratio (1.62\%). Thus, GC-MS data suggested that biofield treatment has significantly altered the isotopic ratio of in treated 4-bromoacetophenone molecule.

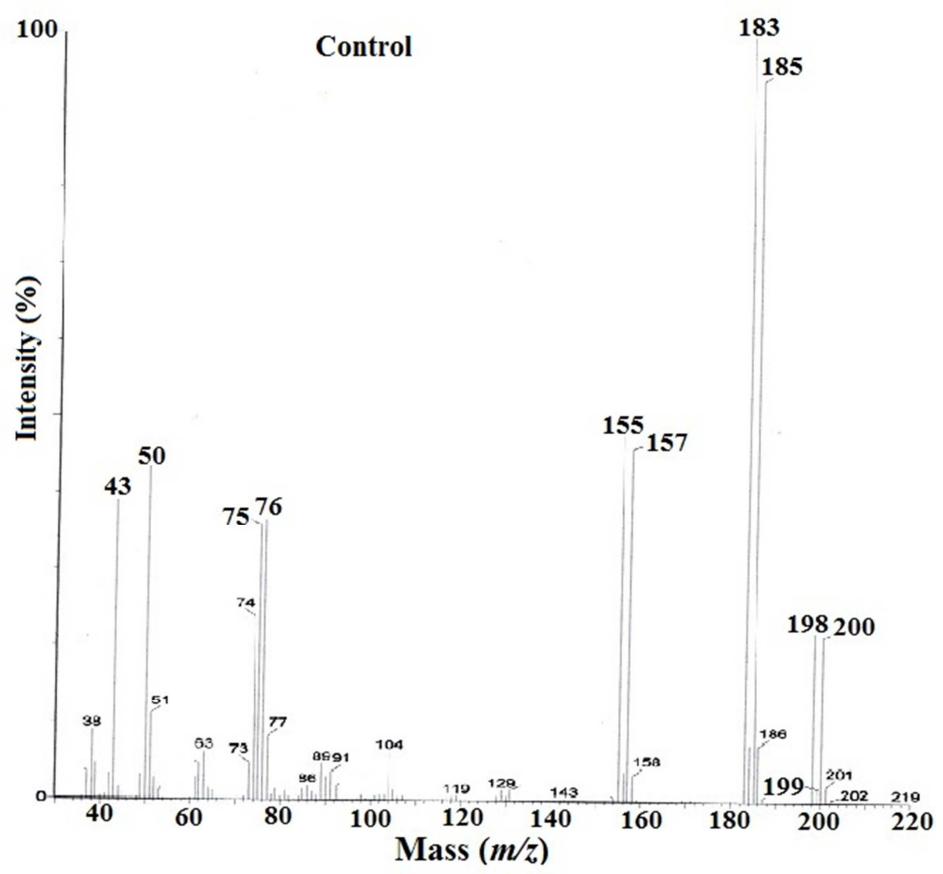

Fig. 4(a). GC-Mass spectra of control sample of 4-bromoacetophenone.

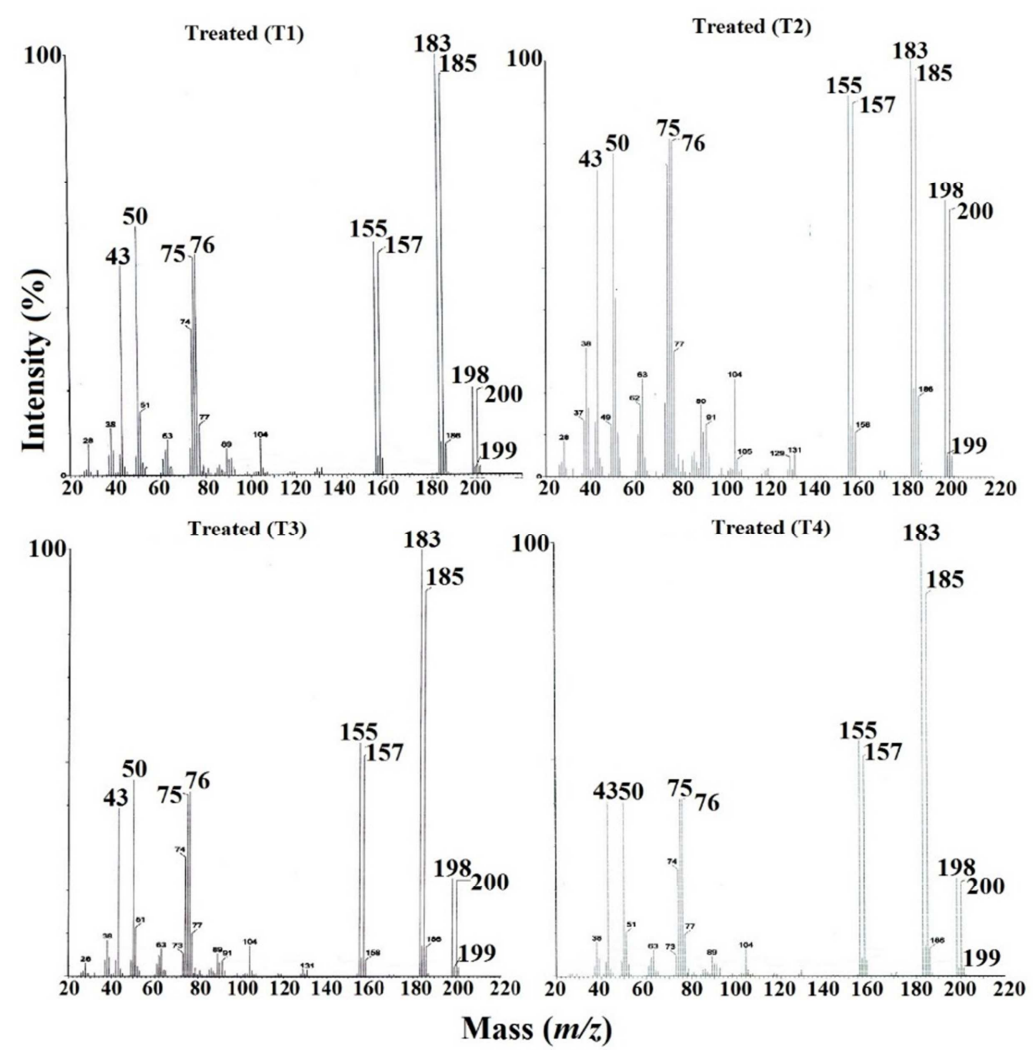

Fig. 4(b). GC-MS spectra of treated (T1, T2, T3 and T4) samples of 4-bromoacetophenone. 


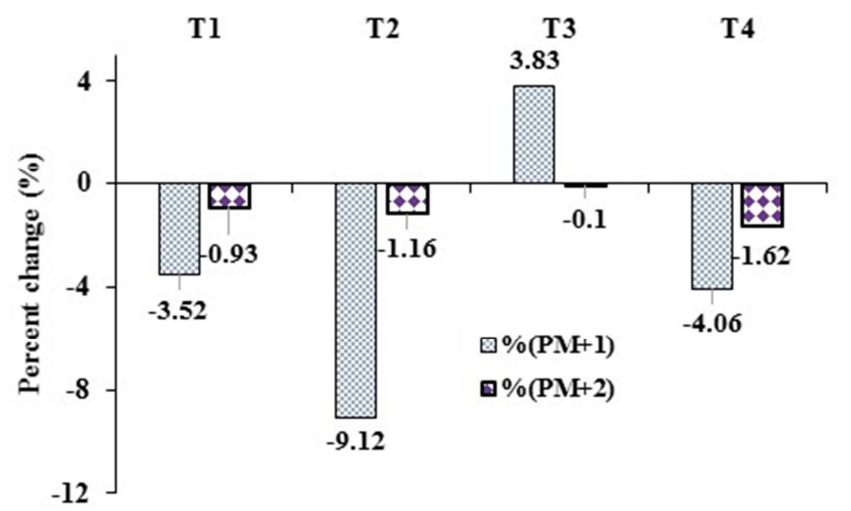

Fig. 5. Percent change in isotopic abundance ratio of $(P M+1) / P M$ and $(P M+2) / P M$ in treated samples of 4-bromoacetophenone.

Table 3. GC-MS isotopic abundance analysis result of 4bromoacetophenone.

\begin{tabular}{llllll}
\hline Parameter & Control & Treated & & \\
\hline & & T1 & T2 & T3 & T4 \\
\hline Peak intensity at $m / z=(\mathrm{PM})$ & 21.93 & 20.47 & 66.46 & 23.00 & 22.74 \\
Peak intensity at $m / z=(\mathrm{PM}+1)$ & 1.91 & 1.72 & 5.26 & 2.08 & 1.96 \\
Peak intensity at $m / z=(\mathrm{PM}+2)$ & 21.38 & 19.77 & 64.04 & 22.04 & 21.82 \\
$\begin{array}{l}\text { Percent change of isotopic } \\
\text { abundance in }(\mathrm{PM}+1) / \mathrm{PM}\end{array}$ & & -3.52 & -9.12 & 3.83 & -4.06 \\
$\begin{array}{l}\text { Percent change of isotopic } \\
\text { abundance in }(\mathrm{PM}+2) / \mathrm{PM}\end{array}$ & & -0.93 & -1.16 & -0.1 & -1.62 \\
\hline
\end{tabular}

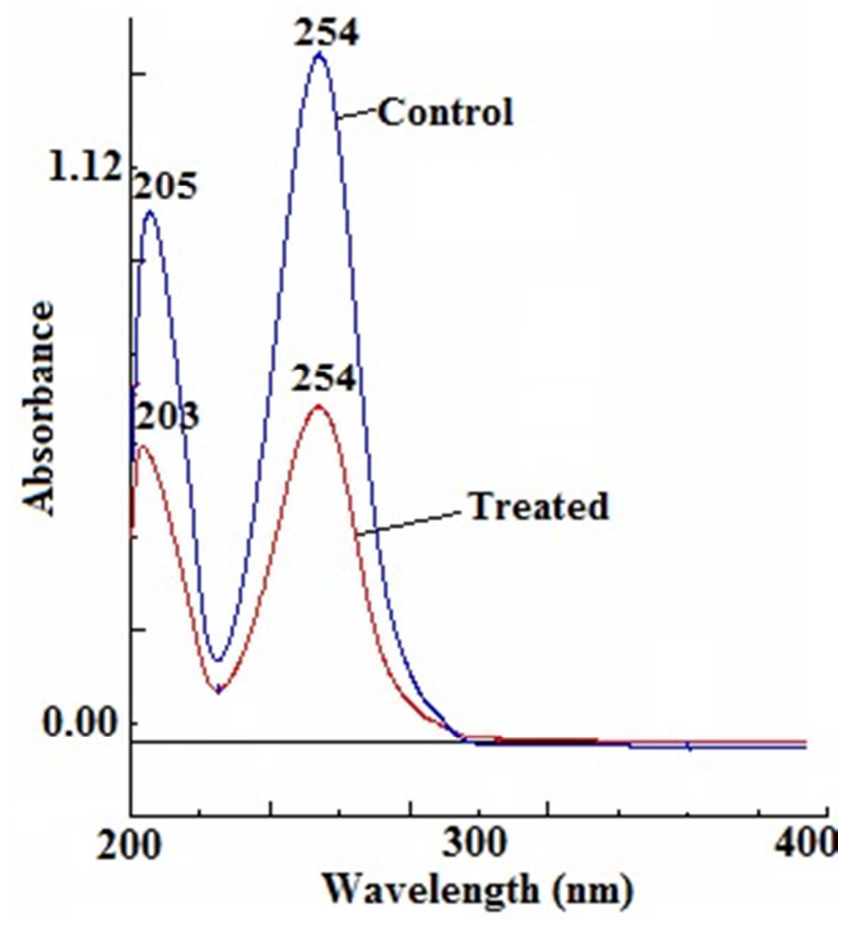

Fig. 6. UV-Vis spectra of control and treated 4-bromoacetophenone sample.

\subsection{UV-Vis Analysis}

The UV spectra of control and treated 4bromoacetophenone are shown in Figure 6. The UV spectrum of control sample showed the absorbance maxima $\left(\lambda_{\max }\right)$ at 205 and $254 \mathrm{~nm}$. Similarly, the spectra of treated sample showed the $\lambda_{\max }$ at 203 and $254 \mathrm{~nm}$. The peak at 254 $\mathrm{nm}$ absorption maximum in control sample did not show any shift of wavelength after biofield energy treatment. However, the peak at higher energy region showed a minor blueshift from $205 \mathrm{~nm}$ (control) to $203 \mathrm{~nm}$ (treated). The result showed that similar pattern but a minor shift of absorbance maxima was exibited by the treated sample as compared to the control. Therefore, it is suggested that the biofield treatment did not disturb the HOMO-LUMO energy gap in the treated sample as compared to the control.

\section{Conclusion}

In summary, the crystallite size was significantly decreased by $16.69 \%$ with decreased intensity of the diffractogram in treated 4-bromoacetophenone as compared to the control. The melting point, latent heat of fusion, and $\mathrm{T}_{\max }$ were decreased slightly by $1.42 \%, 0.85 \%$, and $7.26 \%$, respectively in the treated sample as compared to the control, indicated the reduced thermal stability of the biofield treated 4-bromoacetophenone. The isotopic abundance ratio of $(\mathrm{PM}+1) / \mathrm{PM}$ of treated 4-bromoacetophenone was significantly decreased to $9.12 \%$ in $\mathrm{T} 2$ and slight increased up to $3.83 \%$ in T3 sample as compared to the control. However, the isotopic abundance ratio of $(\mathrm{PM}+2) / \mathrm{PM}$ in treated 4-bromoacetophenone was decreased by $1.62 \%$. It is assumed that due to the lowering of isotopic abundance ratio of $(\mathrm{PM}+1) / \mathrm{PM}$ and $(\mathrm{PM}+2) / \mathrm{PM}$ of treated 4bromoacetophenone, with lower binding energy may lead to lowering of chemical stability than the control sample. The lowering of isotopic abundance is well corroborated with the shifting of $\mathrm{C}=\mathrm{O}$ and $\mathrm{C}=\mathrm{C}$ peak to higher wavenumber region in FT-IR spectra. It is assumed that the lowering of thermal stability in treated 4-bromoacetophenone could make it useful as a reaction intermediate in various coupling reactions and in the synthesis of polymers.

\section{Abbreviations}

XRD: X-ray diffraction

FT-IR: Fourier transform infrared

GC-MS: Gas chromatography-mass spectrometry

DSC: Differential scanning calorimetry

TGA: Thermogravimetric analysis

PM: Primary mass ( $m / z=198$ for 4-bromoacetophenone)

$\mathrm{PM}+1$ : represents isotopic molecule $(\mathrm{m} / z=199)$

$\mathrm{PM}+2$ : represents isotopic molecule $(\mathrm{m} / \mathrm{z}=200)$

\section{Acknowledgments}

The authors would like to acknowledge the whole team of MGV Pharmacy College, Nashik for providing the instrumental facility. We would also like to thank Trivedi Science $^{\mathrm{TM}}$, Trivedi Master Wellness $^{\mathrm{TM}}$ and Trivedi Testimonials for their support during the work. 


\section{References}

[1] Gulcemal S, Cetinkaya B (2013) Palladium-EDTA and palladium-EdteH $\mathrm{H}_{4}$ catalyzed Heck coupling reactions in pure water. Turk J Chem 37: 840-847.

[2] Lu Y, Shi T, Wang Y, Yang H, Yan X, et al. (2009) Halogen bonding- A novel interaction for rational drug design. J Med Chem 52: 2854-2862.

[3] Wender PA, Jeon R (1999) Bromoacetophenone-based photonucleases: Photoinduced cleavage of DNA by 4bromoacetophenone-pyrrolecarboxamide conjugates. Org Lett 1: $2117-2120$.

[4] Laronze M, Boisbrun M, Leonce S, Pfeiffer B, Renard P, et al. (2005) Synthesis and anticancer activity of new pyrrolo4bromoacetophenones and pyrrolo-beta-carbolines. Bioorg Med Chem 13: 2263-2283.

[5] Weskamp T, Bohm VPW, Herrmann WA (1999) Combining N-heterocyclic carbenes and phosphines: Improved palladium (II) catalysts for aryl coupling reactions. J Organomet Chem 585: 348-352.

[6] Kishimoto T, Uraki Y, Ubukata M (2008) Synthesis of bromoacetophenone derivatives as starting monomers for $\beta$-O4 type artificial lignin polymers. J Wood Chem Technol 28: 97-105.

[7] Evans SK, Pearce AA, Ibezim PK, Primm TP, Gaillard AR (2010) Select acetophenones modulate flagellar motility in Chlamydomonas. Chem Biol Drug Des 75: 333-337.

[8] Welch GR (1992) An analogical "field" construct in cellular biophysics history and present status. Prog Biophys Mol Biol 57: 71-128.

[9] Yates FE (1994) Order and complexity in dynamical systems: Homeodynamics as a generalized mechanics for biology. Math Comput Model 19: 49-74.

[10] Rubik B, Pavek R, Ward R, Greene E, Upledger J (1994) Manual healing methods. NIH Publication No. 94-066, Alternative Medicine: Expanding Medical Horizons.
Washington, D. C., US Government Printing Office, 1994a: 134-157.

[11] Rubik B (2002) The biofield hypothesis: Its biophysical basis and role in medicine. J Altern Complement Med 8: 703-717.

[12] Trivedi MK, Patil S, Tallapragada RMR (2015) Effect of biofield treatment on the physical and thermal characteristics of aluminium powders. Ind Eng Manage 4: 151.

[13] Trivedi MK, Patil S, Shettigar H, Bairwa K, Jana S (2015) Phenotypic and biotypic characterization of Klebsiella oxytoca: An impact of biofield treatment. J Microb Biochem Technol 7: 203-206.

[14] Shinde V, Sances F, Patil S, Spence A (2012) Impact of biofield treatment on growth and yield of lettuce and tomato. Aust J Basic Appl Sci 6: 100-105.

[15] Sances F, Flora E, Patil S, Spence A, Shinde V (2013) Impact of biofield treatment on ginseng and organic blueberry yield. Agrivita J Agric Sci 35: 22-29.

[16] Patil SA, Nayak GB, Barve SS, Tembe RP, Khan RR (2012) Impact of biofield treatment on growth and anatomical characteristics of Pogostemon cablin (Benth.). Biotechnology 11: 154-162.

[17] Fuse M, Shirakawa Y, Shimosaka A, Hidaka J (2003) Mechanically strain-induced modification of selenium powders in the amorphization process. J Nanopart Res 5: 97102.

[18] http://webbook.nist.gov/cgi/cbook.cgi?ID=C99901\&Units=C AL\&Type $=$ IR-SPEC.

[19] http://webbook.nist.gov/cgi/cbook.cgi?ID=C99901\&Mask=20 0.

[20] Rieley G (1994) Derivatization of organic-compounds prior to gas-chromatographic combustion-isotope ratio massspectrometric analysis: Identification of isotope fractionation processes. Analyst 119: 915-919.

[21] Eggenkamp H (2014) The geochemistry of stable chlorine and bromine isotopes. In series: Advances in Isotope Geochemistry, Springer-Verlag, Heidelberg. 